\title{
Microelement Supplementation in Dairy Cows by Mineral Lick
}

\author{
Štěpán Krys, Eva Lokajová, Aleš Podhorský, Leoš Pavlata \\ Clinic of Ruminant Diseases, Faculty of Veterinary Medicine, University of Veterinary and Pharmaceutical
} Sciences Brno, Czech Republic

Received December 21, 2007

Accepted November 12, 2008

\begin{abstract}
The aim of this experiment was to verify the option of providing microelement supplementation to dairy cows in the dry period through supplemented mineral lick, and then to compare the content of microelements in the blood, colostrum and milk. The experiment was carried out on a farm with Czech Fleckvieh dairy cows. We formed an experimental group (E), supplied with mineral lick ad libitum enhanced with organic forms of microelements ( $\mathrm{Se}, \mathrm{Zn}, \mathrm{Cu}, \mathrm{Mn}$ ) for four to five weeks before parturition and 1 week after parturition. The control group (C) did not receive any mineral lick. The use of mineral lick by cows was very uneven, its total consumption oscillated between 0 to $250 \mathrm{~g}$ of lick per animal per day. Lick feeding did not result in evidential increase of concentrations of monitored microelements in the cows' blood, colostrum and milk. Only a tendency to increased concentrations of $\mathrm{Se}$ and $\mathrm{Cu}$ in the blood of group $\mathrm{E}$ of cows was observed; the average Se concentration increased by $60 \mu \mathrm{g}^{\cdot l^{-1}}\left(\mathrm{Cu}\right.$ by $\left.9 \mu \mathrm{mol} \cdot \mathrm{l}^{-1}\right)$, whereas in group $\mathrm{C}$, Se increased only by $30 \mu \mathrm{g}^{\cdot l^{-1}}\left(\mathrm{Cu}\right.$ by $\left.6 \mu \mathrm{mol}^{\cdot l^{-1}}\right)$. The concentration of microelements in colostrum after parturition dropped quickly. Significant drops were determined for $\mathrm{Se}, \mathrm{Cu}$ and $\mathrm{Zn}$ on the first (for $\mathrm{Mn}$ on the second) day after parturition. Selenium concentration in the first colostrum was 5 times higher than in milk, $\mathrm{Cu}$ concentration 3 times higher, $\mathrm{Zn}$ concentration 4 times higher and Mn concentration 1.3 times higher.
\end{abstract}

Selenium, copper, manganese, zinc, trace elements metabolism, blood, colostrum, milk

Microelements are nutritional components that occur and function in many locations and on many levels of organism. They are present in the organism at very low concentrations and are an indispensable component in numerous enzymatic, catalytic, regulating and activating processes, usually as activators and co-factors. Microelements enter the organism through the feed; in developing foetuses they enter through the placenta. Concentration of microelements in blood of supplemented mothers correlates positively with concentrations in calf blood. An important source of microelements for a newborn calf is the colostrum (Abdelrahman and Kincaid 1993; Lacetera 1996; Underwood and Suttle 1999; Pavlata et al. 2003).

Microelements also affect the quality and composition of the colostrum and milk and affect the health of the udder. For example, the colostrum and milk of selenium-supplemented cows has a higher concentration of selenium and contains a higher concentration of immunoglobulins; cows supplied with selenium have lower incidence of mastitis (Hogan et al. 1993; Knowles et al. 1999; Pavlata et al. 2004a); supplementation of zinc to dairy cows decreases the number of somatic cells in milk (Pechová et al. 2006), and copper affects the ability of neutrophils to kill phagocytosed bacteria and decreases susceptibility of the udder to infection (Scaletti et al. 2003).

Microelement deficiencies in dairy and beef cattle in the Czech Republic are frequent (Pavlata et al. 2005a; Slavík et al. 2006; Podhorský et al. 2007). Ruminant nutrition routinely uses several methods and forms to supplement microelements. A slightly problematic period for ensuring adequate supplementation of microelements to dairy cows is the dry period, when only a small amount of seeds is usually fed and microelements are thus difficult to add to the feed. Application forms include supplementation by adding minerals to the feed, mineral licks, and/or single/repeated injection of individual

Address for correspondence:

Doc. MVDr. Leoš Pavlata, Ph.D., Dipl. ECBHM

Clinic of Ruminant Diseases, Faculty of Veterinary Medicine

University of Veterinary and Pharmaceutical Sciences Brno

Palackého 1-3, 61242 Brno, Czech Republic
Phone: +420541562407

Fax: +420541562407

E-mail: pavlatal@vfu.cz

http://www.vfu.cz/acta-vet/actavet.htm 
microelements, or combinations of the above. Other methods of supplementation include boluses, projectiles or pills (depending on the shape of administration form), containing a precisely defined amount of microelements combined with a carrier or auxiliary substance. Another method of supplementation of microelements consists in long-acting injections (Lee et al. 1999; Pavlata 2004a; Kinal et al. 2004; Pechová et al. 2006; Mulligan et al. 2006; Chládek and Zapletal 2007).

The purpose of our experiment was to verify the option of providing supplementation of microelements to dairy cows in the dry period by supplementation of microelements in mineral lick and then comparing the levels of microelements in the blood, colostrum and milk of supplemented and non-supplemented dairy cows.

\section{Materials and Methods}

The experiment was conducted on a farm with Czech Fleckvieh dairy cows. In a barn with the capacity of 400 dairy cows, we formed two groups of late-pregnant dry cows, the experimental - E $(n=12)$ and the control - C $(\mathrm{n}=8)$. The cows were divided into groups according to the predefined concentrations of $\mathrm{Mn}, \mathrm{Cu}$ and $\mathrm{Zn}$ in blood and according to glutathione peroxidase activity (GSH-Px) as an indirect indicator of selenium supplementation, so that average values for both groups were as balanced as possible.

All cows were given the same feed $(2 \mathrm{~kg}$ of hay, $2 \mathrm{~kg}$ of straw, $8 \mathrm{~kg}$ of corn silage, $7 \mathrm{~kg}$ of GPS, $2 \mathrm{~kg}$ of alfalfa silage, $0.4 \mathrm{~kg}$ of soy, $0.4 \mathrm{~kg}$ of rape), which was supplemented in the period of preparation for parturition with $2 \mathrm{~kg}$ of grain mixture (wheat, barley, soy), and with $4 \mathrm{~kg}$ of the same grain mixture in the first week after parturition. For 4-5 weeks before the expected date of parturition and 1 week after parturition, the experimental group of cows had access ad libitum to the mineral lick PP VSV - mineral feed for cattle, dairy cows and calves with microelement content manufactured by TREWIT Ltd. in the following composition: sodium chloride, magnesium oxide, calcium dihydrogen and hydrogen phosphate, calcite, ammonium dihydrogen phosphate, brewer's yeast, chelate of zinc and amino acids n-hydrate, $\mathrm{Zn}(\mathrm{x}) 1-3 \cdot \mathrm{nH}_{2} \mathrm{O}$, chelate of manganese and amino acids n-hydrate, $\mathrm{Mn}(\mathrm{x}) 1-3 \cdot \mathrm{nH}_{2} \mathrm{O}$, chelate of copper and amino acids n-hydrate, $\mathrm{Cu}(\mathrm{x}) 1-3 \cdot \mathrm{nH}_{2} \mathrm{O}, \mathrm{SELPLEX}$ with declared quality characteristics presented in Table 1.

Table 1. Composition of the mineral lick available to experimental group cows

\begin{tabular}{|lr|lr|}
\hline At humidity $(\%)$ & 5 & $\mathrm{Mg}(\%)$ & 8 \\
\hline Ash $(\%)$ & 95 & $\mathrm{Cu}\left(\mathrm{mg} \cdot \mathrm{kg}^{-1}\right)$ & 900 \\
\hline $\mathrm{Ca}(\%)$ & 10 & $\mathrm{Zn}\left(\mathrm{mg} \cdot \mathrm{kg}^{-1}\right)$ & 2100 \\
\hline $\mathrm{P}(\%)$ & 5 & $\mathrm{Mn}\left(\mathrm{mg} \cdot \mathrm{kg}^{-1}\right)$ & 2100 \\
\hline $\mathrm{Na}(\%)$ & 11 & $\mathrm{Se}\left(\mathrm{mg} \cdot \mathrm{kg}^{-1}\right)$ & 6 \\
\hline
\end{tabular}

repeatedly during its course (14 days before the exp 20 days parturition, 4 and was examined. Before the start of the experiment, the concentration of $\mathrm{Zn}, \mathrm{Cu}, \mathrm{Mn}$ and GSH-Px activity were determined. During the following sampling, we determined concentrations of $\mathrm{Zn}, \mathrm{Cu}, \mathrm{Mn}$ and Se. On the day of parturition (day 0), blood was sampled together with the first colostrum, in which concentrations of the monitored microelements were determined. Concentrations of microelements were determined in the colostrum on the $1^{\text {st }}$, $2^{\text {nd }}, 3^{\text {rd }}$ and $4^{\text {th }}$ day p.p., and in milk on the $20^{\text {th }}$ day p.p.

Selenium in the whole blood, colostrum and milk was determined using the method developed by Pechová et al. (2005) with the AAS hydride technique, and glutathione peroxidase activity using the method developed by Paglia and Valentine (1967) using RANSEL - RANDOX set. The status of organism supplementation with Zn and $\mathrm{Cu}$ was assessed based on the concentration of these elements in blood serum and determined using flame AAS. Mn concentration was determined in the whole blood, colostrum and milk after microwave mineralization of the sample (Pechová et al. 2005) with electrothermic AAS. After microwave mineralization of the sample, the concentration of $\mathrm{Zn}$ and $\mathrm{Cu}$ in the colostrum was measured using flame or electrothermic AAS. All examinations were carried out in the biochemical laboratory of the Clinic of Ruminant Diseases at the University of Veterinary and Pharmaceutical Sciences Brno.

Basic statistical treatment of the results (mean value, standard deviation) of individual groups and their mutual comparison were carried out using Microsoft Excel XP software. The results were evaluated using F-test for analysis of variance of individual files values and, according to results, using paired Student's $t$-test for files with equal/unequal sample sizes. Dynamics of changes in concentrations of microelements in the colostrum and milk were evaluated by comparison of results using paired $t$-test. Results at the significance level of $p \leq 0.05$ are evaluated as significant. 


\section{Results and Discussion}

The intake of mineral lick by cows was very uneven and its total consumption was between 0 and $10.54 \mathrm{~kg}$, i.e. $0-250 \mathrm{~g}$ mineral lick per animal per day. Two dairy cows from the experimental group that received no lick in the entire period were removed from further assessment. After the removal, the average lick intake for the entire experiment period was $6.47 \pm 2.58 \mathrm{~kg}$ per animal, i.e. $150 \mathrm{~g}$ per animal per day, ranging $60-250 \mathrm{~g}$ per animal per day.

Our results and data of other authors indicate that mineral lick does not appear to be a suitable form of microelement supplementation of dairy cows. Some cows did not accept mineral lick at all. Valk and Kogut (1998) described their experience with mineral lick use - they monitored reception of blocks with and without $\mathrm{NaCl}$. Differences in the intake were from 0 to $70 \mathrm{~g}$ of lick per day. Other studies also showed substantial differences in the acceptance of mineral blocks by individual cows. Lobato et al. (1980) describe the range of intake of molasses blocks between 0 and 105 grams per animal per day. In another study dealing with molasses blocks (Graham et al. 1977) the consumed amount varied between 0 and $387 \mathrm{~g} \cdot$ day $^{-1}$. Eggington et al. (1990) found even bigger variation - they described the range in acceptance of salt block between $10 \mathrm{~g}$ and $835 \mathrm{~g} \cdot$ day $^{-1}$. Apart from variations in the amount of lick intake, there were variations in the acceptance of molasses blocks (of identical composition) made by different manufacturers (Ducker et al. 1981; Kendall et al. 1983). We may say that many factors play a role in the intake of mineral lick. The amount of lick can be affected by its taste or shape. It seems that the lick acceptance is not in a direct proportion to the needs of dairy cows, but rather to their taste and will. The intake can also be influenced by the block shape, location or ease of access. Lick appetite can also be affected by the distance the cow must go to reach it. The acceptance of lick may also be determined by age or previous experience. Lick hardness also appears to be an important factor. It was observed that cows prefer a softer lick enabling them to receive more in a shorter period.

Tait and Fisher (1996) present the problem of lick hardening due to air humidity and cow saliva. As a result, cows must spend a longer time to consume the same amount of lick, which negatively affects consumption. The issue could be solved by production of waterresistant licks that preserve constant hardness and thus also the time required for an animal to obtain the same amount of minerals. Mitchell (1972) described the relation between the appetite to consume salt and the amound of potassium in feed, and Cunha (1987) found that the consumption of calcium increases with a high content of potassium in feed. This influences the appetite to consume mineral lick containing salt. However, Chládek and Zapletal (2007) did not corroborate these results. They found a negative correlation between the higher salt content in mineral lick and the appetite to consume it. The also found the intake of lick to be affected by season; in winter, the consumption of lick was lower than in the pasture period.

Before the microelement supplementation by mineral lick began, the levels of monitored microelements in the blood of animals of both groups were very even. In the cows of group $\mathrm{C}$ and $\mathrm{E}$, the average concentration of $\mathrm{Cu}$ was $12 \mu \mathrm{mol} \cdot \mathrm{l}^{-1}$ in the blood serum, $\mathrm{Zn} \mathrm{18}$, or $17 \mu \mathrm{mol}^{-1} \mathrm{l}^{-1}$ in the blood serum, Mn 0.16 , or $0.19 \mu \mathrm{mol} \cdot \mathrm{l}^{-1}$ in the whole blood, and GSH-Px activity in the whole blood (as an indirect indicator of the level of organism supplementation with selenium) $600 \mu \mathrm{kat}^{-1} \mathrm{l}^{-1}$. Based on these results and comparison with recommended values (Pavlata et al. 2000; Pechová et al. 2004) we may conclude that dairy cows suffered from manganese deficiency (values exceeding $0.4 \mu \mathrm{mol} \cdot \mathrm{l}^{-1}$ are required), marginal copper deficiency (values exceeding $12.6 \mu \mathrm{mol}^{\cdot 1-1}$ are required) and selenium deficiency (values exceeding GSH-Px $600 \mu \mathrm{kat}^{-1} \mathrm{l}^{-1}$ are required). The level of zinc was sufficient (values exceeding $12.2 \mu \mathrm{mol} \cdot \mathrm{l}^{-1}$ are required). 

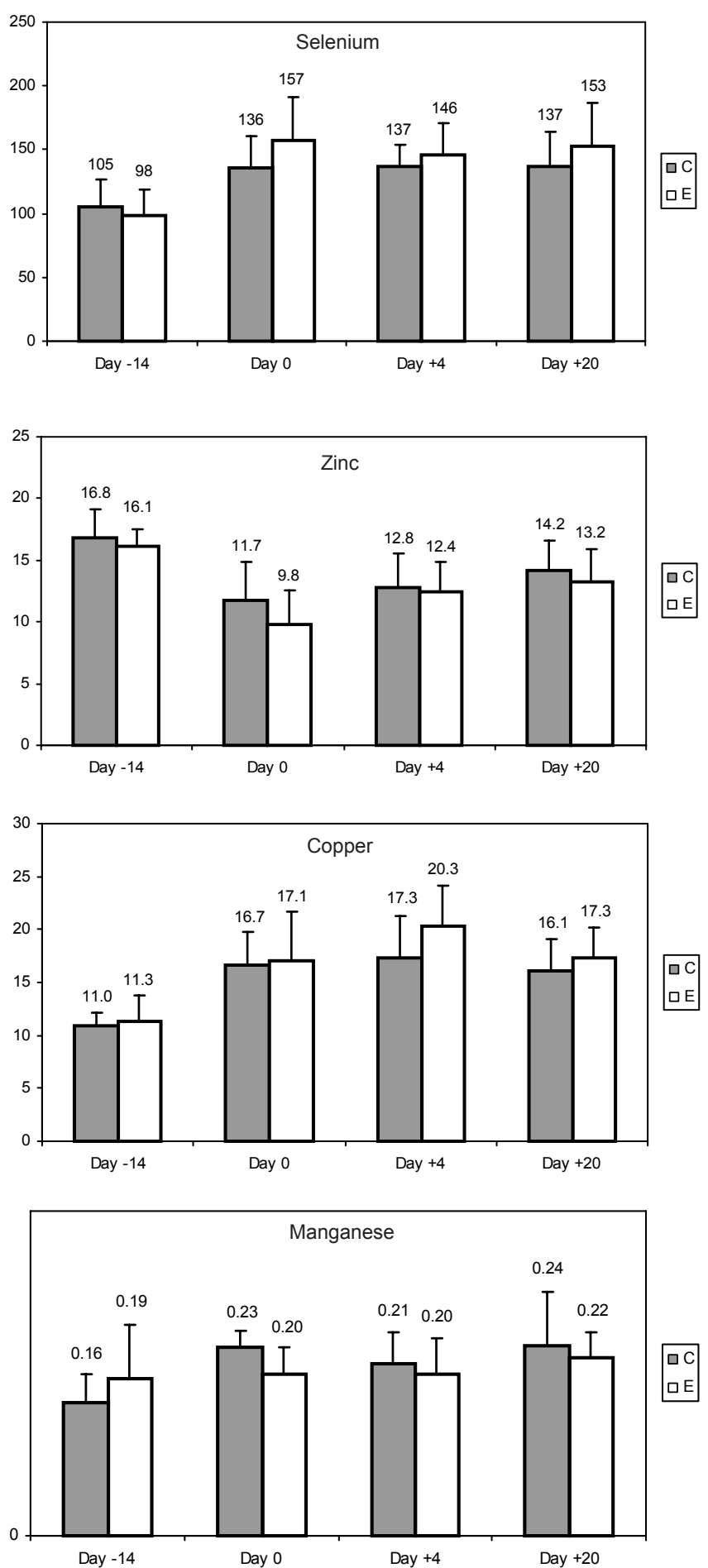

The results of blood examination of experimental (E) and control (C) cows during the experiment are shown in Figs 1-4.

Comparing the mean values of concentrations of microelements before the start of supplementation with values 14 days before parturition, we found no significant increase in the experimental group, and the concentration of none of the monitored elements differed substantially between the experimental and the control groups.

The figures reveal that in the subsequent period, when the levels of microelements in blood were determined, the concentrations ofmonitored microelements in blood of cows were gradually increasing, excluding zinc. This increase, recorded mainly in the period around parturition, was established in cows from both groups and no significant differences were recorded between the groups with and without the mineral lick intake. The only visible trend is higher selenium concentration increase in cows of group E, where the blood concentration of selenium increased by nearly $60 \mu \mathrm{g} \cdot \mathrm{l}^{-1}$, between day 14 before parturition

Figs 1-4. Concentration of microelements in the blood (Se - $\left.\mu \mathrm{g} \cdot \mathrm{l}^{-1} ; \mathrm{Zn}, \mathrm{Cu}, \mathrm{Mn}-\mu \mathrm{mol} \cdot \mathrm{l}^{-1}\right)$ of examined cows of the control (C) and experimental $=$ supplemented (E) groups during the evaluated period (mean \pm standard deviation) 


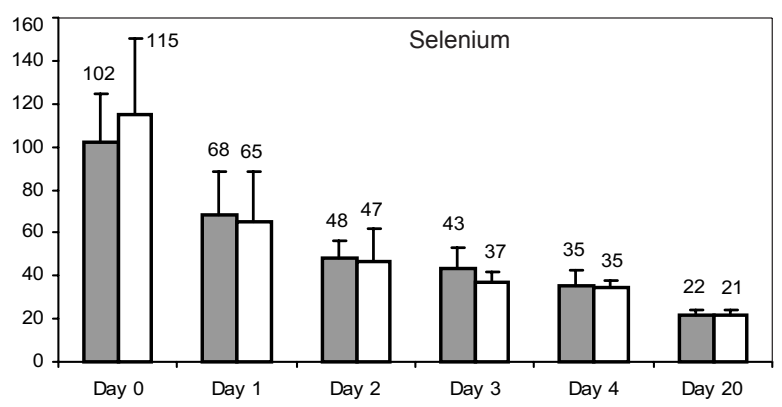

and the day of the parturition, whereas in group $\mathrm{C}$ of cows it was approximately only by $30 \mu \mathrm{g} \cdot \mathrm{l}^{-1}$. Regarding copper, the trend to its higher concentration in blood also exists in the lick-receiving group, where in the period between 14 days before parturition and day 4 after parturition, the concentration of copper increased by $9 \mu \mathrm{mol} \cdot \mathrm{l}^{-1}$ (average) compared to group $\mathrm{C}$, in which the concentration increased by only $6.3 \mu \mathrm{mol} \cdot \mathrm{l}^{-1}$. Concerning the rest of the examined variables, there are no clear differences between the groups and we may state that lick feeding did not lead to any significant increase in concentrations of the monitored microelements in the cows' blood.

Changes in individual indicators of blood of both groups of cows can be linked to physiological changes that occur in the period around parturition. Increased concentrations $\begin{array}{ll}\mathrm{aC} & \text { Inces } \\ \mathrm{aE} & \text { of Se, } \mathrm{Cu} \text { and } \mathrm{Mn} \text { in blood }\end{array}$ are related not only to lick intake, but probably mainly to the feeding of higher amounts of seeds in the parturition preparation period and in the period after parturition, as they contain naturally higher concentrations of microelements. Decreased

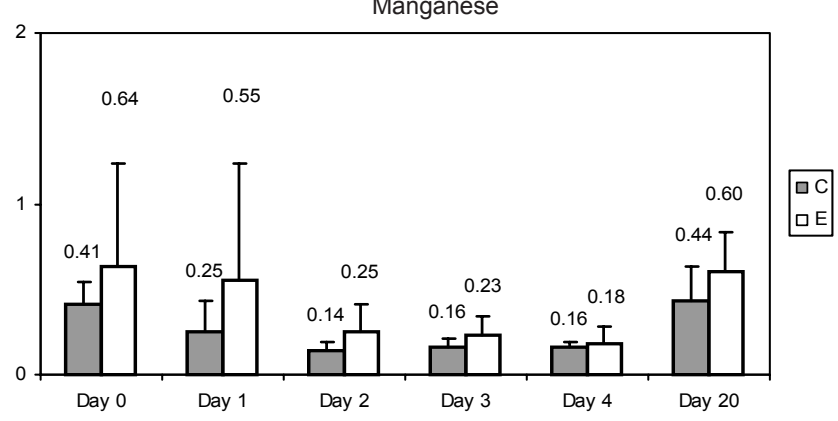

Figs 5-8. Concentrations of microelements (Se - $\mu \mathrm{g} \cdot \mathrm{l}^{-1}$; $\left.\mathrm{Zn}, \mathrm{Cu}, \mathrm{Mn}-\mu \mathrm{mol}^{-1} \mathrm{l}^{-1}\right)$ in the colostrum (day 0 to 4 ) and milk (day 20) of the experimental (E) and control (C) groups of cows (mean \pm standard deviation) 
concentrations of $\mathrm{Zn}$ in both groups after parturition result from a higher consumption of zinc by the developing foetus in late gravidity and primarily from a high $\mathrm{Zn}$ release in the colostrum that contains $\mathrm{Zn}$ at high concentrations (Pavlata et al. 2004b).

The results of examinations of the colostrum and milk of experimental (E) and control (C) cows are shown in Figs 5-8.

Although the measured results of concentrations of microelements in colostrum and milk show several variations between the groups, no significant difference was found between the groups $\mathrm{E}$ and $\mathrm{C}(p>0.05)$. Only certain trends to variation between groups are traceable.

Selenium concentration in the colostrum was the highest on the day of parturition, and gradually decreased until day 20 p.p. The initial drop was quick, but it slowed down soon. Similar dynamism of Se concentration in the colostrum and milk was described by Kráčmar et al. (2003) in goats. Contrary to our findings, they observed a transitional concentration increase ca $48 \mathrm{~h}$ after parturition. In another study, Kráčmar et al. (2005) described the dynamism of Se concentration changes in the sheep colostrum, with a decrease starting 48 $\mathrm{h}$ after parturition.

The monitored copper concentration in the colostrum and milk showed non-significant differences between groups. The highest $\mathrm{Cu}$ concentration occurred on the day of parturition, and then it decreased, and increased slightly on the day 4 p.p. The increase was probably only transitional, since $\mathrm{Cu}$ concentration in milk on day 20 p.p. was lower again. Kume and Tanabe (1993) describe similar dynamism of $\mathrm{Cu}$ concentrations in the colostrum. In their experiment, $\mathrm{Cu}$ concentration was the highest on the day of parturition, decreasing steeply until day two, approximately to the concentration level in milk. However, Kincaid and Cronrath (1992) arrived at different results. They measured the highest $\mathrm{Cu}$ concentration on the day of parturition, but its subsequent decrease was slower and since day 3 the $\mathrm{Cu}$ amount in the colostrum and later in milk remained stable.

Zinc concentration was the highest on the day of parturition, it fell sharply until the next day, and kept decreasing in subsequent days. Kume and Tanabe (1993) observed the same dynamism of $\mathrm{Zn}$ concentrations in the colostrum and milk. Kincaid and Cronrath (1992) deal with $\mathrm{Zn}$ concentrations in the period around parturition in more detail. $\mathrm{Zn}$ concentration on the day of parturition increased sharply compared to periods before parturition and after parturition. The authors also observed that the concentration drops sharply until day 2 and then keeps declining slowly in the following days.

The difference in Mn concentrations on the day of parturition and on day 1 after parturition was rather high, however, due to large standard deviations, a significant difference could not be established. The dynamism of manganese concentrations in the colostrum had a similar course as the dynamism of other monitored microelements. We found the highest concentration on the day of parturition, on day 1 p.p. the concentration dropped sharply, and the decline continued in the subsequent days. Contrary to the other monitored microelements, with $\mathrm{Mn}$ we found increased concentration in milk on day 20 p.p. compared to concentration in the colostrum on day 4. Kume and Tanabe (1993) arrived at similar results in their study, finding the highest concentration in the colostrum on the day of parturition, with a sharp decrease until day two, continuing in the following days. However, Kincaid and Cronrath (1992) found that the concentration of manganese, contrary to some other elements, does not increase on the day of parturition, and its concentration in the period around parturition remains at an approximately identical level, and thus the dynamism of its concentrations in the time after parturition does not show any significant changes.

The concentration of microelements in the colostrum and milk after parturition changes in time substantially, peaking in the first colostrum and declining gradually. In all the monitored microelements (excluding $\mathrm{Mn}$ ) the concentration in milk is much lower than the 
concentration in the first colostrum. The measured concentrations of $\mathrm{Cu}, \mathrm{Zn}$, and Se reach only $20-35 \%$ of the values in the first colostrum.

\section{Dotace mikroprvků dojnicím prostřednictvím minerálního lizu}

Cílem práce bylo ověrit možnost zajištění dotace mikroprvků dojnicím v období stání na sucho prostřednictvím dotace minerálního lizu a následně porovnat obsah mikroprvků v krvi, kolostru a v mléce dotovaných a nedotovaných dojnic. Pokus byl realizován na farmě dojnic českého strakatého plemene. Byla vytvořena skupina pokusná (E), které byl v období čtyř až pěti týdnů před porodem až do konce prvního týdne po porodu adlibitně podáván minerální liz obohacený organicky vázánými mikroprvky (Se, Zn, Cu, Mn). Kontrolní skupina (C) minerální liz nedostávala. Př́jem minerálního lizu krávami byl velmi nevyrovnaný, jeho celková spotřeba se pohybovala v rozmezí 0-250 g minerálního lizu $\mathrm{ks}^{-1} \cdot \mathrm{den}^{-1}$. Zkrmování lizu nevedlo k průkaznému zvýšení koncentrací sledovaných mikroprvků v krvi krav, kolostru a mléce. Byl pouze pozorován trend ke zvýšení koncentrací Se a $\mathrm{Cu} v$ krvi krav skupiny $\mathrm{E}$, kde průměrná koncentrace Se stoupla o $60 \mu \mathrm{g} \cdot \mathrm{l}^{-1}$ a $\mathrm{Cu}$ o $9 \mu \mathrm{mol} \cdot \mathrm{l}^{-1}$, zatímco u skupiny $\mathrm{C}$ stoupl Se jen o $30 \mu \mathrm{g} \cdot \mathrm{l}^{-1}$ a Cu o $6 \mu \mathrm{mol} \cdot \mathrm{l}^{-1}$. Koncentrace mikroprvků v kolostru po porodu rychle klesala. Signifikantní pokles byl zjištěn u Se, Cu a Zn již první a u Mn druhý den po porodu. Koncentrace Se v prvním kolostru je 5krát vyšší než v mléce, koncentrace $\mathrm{Cu}$ je vyšší 3krát, koncentrace Zn 4krát a koncentrace Mn 1,3krát vyšší.

\section{Acknowledgement}

The work was supported by the Research Project of the Ministry of Education, Youth, and Sports No. MSM6215712403.

\section{References}

Abdelrahman MM, Kincaid RL 1993: Deposition of copper, manganese, zinc, and selenium in bovine fetal tissue at different stages of gestation. J Dairy Sci 76: 3588-3593

Cunha TJ 1987: Salt and trace minerals. Salt institute, Alexandria VA, 238 p.

Du Z, Hemken RW, Harmon RJ 1996: Copper metabolism of Holstein and Jersey cows and heifers fed diets high in cupric sulfate or copper proteinate. J Dairy Sci 79: 1873-1880

Ducker MJ, Kendall PT, Hemingway RG, McClelland TH 1981: An evaluation of feedblocks as a means of providing supplementary nutrients to ewes grazing upland/hill pastures. Anim Prod 33: 51-57

Eggington AR, McCosker TH, Graham CA 1990: Intake of lick block supplements by cattle grazing native monsoonal tallgrass pastures in the Northern Territory. Aust Rangel J 12: 7-13

Graham CA, Pern C, Linehan KL 1977: Individual daily consumption of a medicated bloat blocks. Aust J Exp Agric Anim Husb 17: 562-565

Hogan JS, Weiss WP, Smith KL 1993: Role of vitamin E and selenium in host defense against mastitis. J Dairy Sci 76: $2795-2803$

Chládek G, Zapletal D 2007: A free-choice intake of mineral blocks in beef cows during the grazing season and in winter. Livest Sci 106: 41-46

Kendall PT, Ducker MJ, Hemingway RG 1983: Individual intake variation in ewes given feedblocks or trough supplements indoors or at winter grazing. Anim Prod 36: 7-19

Kinal S, Rzasa A, Korniewicz A 2004: Mineral bioplex supplementation of diets for cows affects colostrum quality and immunoglobulins in calf blood serum. J Anim Feed Sci 13 (Suppl.): 79-82

Kincaid RL, Cronrath JD 1992: Zinc concentration and distribution in mammary secretion of peripartum cows. J Dairy Sci 75: 481-484

Knowles SO, Grace ND, Wurms K, Lee J 1999: Significance of amount and form of dietary selenium on blood, milk, and casein selenium concentrations in grazing cows. J Dairy Sci 82: 429-437

Kráčmar S, Gajdůšek S, Jelínek P, Illek J 2003: Changes in contents of some macro- and microelements in goat's colostrum within the first 72 hours after parturition. Small Ruminant Res 49: 213-218

Kráčmar S, Kuchtík J, Baran M, Váradyová Z, Kráčmarová E, Gajdůšek S, Jelínek P 2005: Dynamics of changes in contents of organic and inorganic substances in sheep colostrum within the first $72 \mathrm{~h}$ after parturition. Small Ruminant Res 56: 183-188

Kume S, Tanabe S 1993: Effect of parity on colostral mineral concentrations of Holstein cows and value of colostrum as a mineral source for newborn calves. J Dairy Sci 76: 1654-1660

Lacetera N, Bernabucci U, Ronchi B, Nardone A 1996: Effects of selenium and vitamin E administration during a late stage of pregnancy on colostrum and milk production in dairy cows, and on passive immunity and growth of their offspring. Am J Vet Res 57: 1776-1780 
Lee J, Masters DG, White CL, Grace ND, Judson GJ 1999: Current issues in trace element nutrition of grazing livestock in Australia and New Zealand. Aust J Agric Res 50: 1341-1364

Lobato JFP, Pearce GR, Tribe DE 1980: Measurement of variability in intake by sheep of oat grain, hay and molasses-urea blocks using chromic oxide as a marker. Aust J Exp Agric Anim Husb 20: 413-416

Mitchell AR 1972: Appetite, an aspect of potassium balance in ruminant. Br Vet J 128: 76-77

Mulligan F, O'Grady L, Rice D, Doherty M 2006: A herd health approach to dairy cow nutrition and production diseases of the transition cow. Anim Reprod Sci 96: 331-353

Paglia DD, Valentine WN 1967: Studies on the quantitative and qualitative characterisation of erythrocyte gluthatione peroxidase. J Lab Clin Med 70: 158-169

Pavlata L, Pechová A, Dvořák R 2004b: Microelements in colostrum and blood of cows and their calves during colostral nutrition. Acta Vet Brno 73: 421-429

Pavlata L, Pechová A, Illek J 2000: Direct and indirect assessment of selenium status in cattle - a comparison. Acta Vet Brno 69: 281-287

Pavlata L, Podhorský A, Pechová A, Chomát P 2005a: Differences in the occurrence of selenium, copper and zinc deficiencies in dairy cows, calves, heifers and bulls. Vet Med-Czech 50: 390-400

Pavlata L, Prášek J, Podhorský A, Pechová A, Haloun T 2003: Selenium metabolism in cattle: maternal transfer of selenium to newborn calves at different selenium concentrations in dams. Acta Vet Brno 72: 639-646

Pavlata L, Prášek J, Filípek J, Pechová A 2004a: Influence of parenteral administration of selenium and vitamin E during pregnancy on selected metabolic parameters and colostrum quality in dairy cows at parturition. Vet Med-Czech 49: 149-155

Pechová A, Pavlata L, Hofírek B, Dvořák R 2004: Metabolic profile test. In: Hofírek B, Pechová A, Doležel R, Pavlata L, Dvořák R, Fleischer P et al. (Eds): Herd health management in dairy cattle (in Czech). VFU Brno, pp. 31-49

Pechová A, Pavlata L, Illek J 2005: Blood and tissue selenium determination by hydride generation atomic absorption spectrophotometry. Acta Vet Brno 74: 483-490

Pechová A, Pavlata L, Lokajová E 2006: Zinc supplementation and somatic cell count in milk of dairy cows. Acta Vet Brno 75: 355-361

Podhorský A, Pechová A, Dvořák R, Pavlata L 2007: Metabolic disorders in dairy calves in postpartum period. Acta Vet Brno 76: 45-53

Scaletti RW, Trammell DS, Smith BA, Harmon RJ 2003: Role of dietary copper in enhancing resistance to Escherichia coli mastitis. J Dairy Sci 86: 1240-1249

Slavík P, Illek J, Zelený T 2006: Zinc and copper status of beef cattle in the Šumava region, Czech Republic. Acta Vet Brno 75: 485-488

Spears JW 2003: Trace mineral bioavailability in ruminants. J Nutr 133: 1506S-1509S

Tait RM, Fisher LJ 1996: Variability in individual animal's intake of minerals offered free-choice to grazing ruminants. Anim Feed Sci Technol 62: 69-76

Underwood EJ, Suttle NF 1999: Mineral nutrition of livestock. CABI Publishing, Wallingford, 624 p.

Valk H, Kogut J 1998: Salt block consumption by high yielding dairy cows fed rations with different amounts of $\mathrm{NaCl}$. Liv Prod Sci 56: 35-42 